\title{
PENGARUH MENGKONSUMSI MINUMAN MADU TERHADAP TINGKAT KEASAMAN PH SALIVA ANAK SEKOLAH DASAR
}

\author{
Dwi Eni Purwati ${ }^{{ }^{1}}$ Siti Sulastri $^{2}$
}

\begin{abstract}
ABSTRAK
Masyarakat dapat memanfaatkan obat tradisional misalnya madu sebagai obat alternatif untuk mengurangi pembentukan plak gigi. Madu alami banyak mengandung enzim, yaitu molekul protein yang sangat komplek, yang dihasilkan oleh sel hidup dan berfungsi sebagai katalisator, yakni : zat pengubah kecepatan reaksi dalam proses kimia yang terjadi di dalam tubuh setiap makhluk hidup. Madu mengandung antibiotik sebagai antibakteri dan antiseptik menjaga luka. Berdasarkan studi pendahuluan kepada 10 siswa pemeriksaan saliva siswa rata-rata $\mathrm{pH}$ saliva kurang dari 7 dibawah normal, dan siswa mempunyai karies gigi rata-rata 2. Tujuan Penelitian diketahuinya rata-rata tingkat keasaman $p H$ saliva sebelum dan sesudah mengkonsumsi minuman madu.

Jenis penelitian Quasi Eksperimen, penelitian menggunakan Rancangan Pretest-Posttest With Control Group. Jumlah sampel 60 siswa, dengan cara random sampling. Analisis dengan Uji T-Test.

Hasil penelitian pH sebelum dan sesudah mengkonsumsi minuman madu signifikansinya adalah $p=0,05<0,05$. Kesimpulan penelitian ini adalah adanya pengaruh minuman madu terhadap nilai $p H$ saliva.
\end{abstract}

Kata Kunci : minuman madu, $\mathrm{pH}$ saliva

\begin{abstract}
Communities can take advantage of traditional medicine such as honey as an alternative medicine to reduce the formation of dental plaque. Honey containing antibiotics as antibacterial and antiseptic keeping the wound. Natural honey contains a lot of enzymes, that is very complex of protein molecul, produced by living cells and have function as catalyst, which is: The speed reaction modifier substance in the chemical process. The process happened within the body of every living beings. Based on preliminary studies to 10 students saliva examination average student salivary $\mathrm{pH}$ less than 7 below normal, and students have an average of dental caries 2. Research objective is to know the average level of acidity $\mathrm{pH}$ of saliva before and after drinking honey.

Quasi-Experimental research type, research using pretest-posttest design With Control Group. Total sample of 60 students, by means of random sampling. Test analysis by T-Test.

PH study results before and after drinking the honey of significance is $p=0.05<0.05$. The conclusion of this study was there was the influence of drink honey to salivary $\mathrm{pH}$ values.
\end{abstract}

Keywords : drink honey, the pH of saliva

$\overline{1,2)}$ Dosen Jurusan Keperawatan Gigi Poltekkes Kemenkes Yogyakarta

凶: $\underline{\text { dwienipurwati79@gmail.com }}$ 


\section{PENDAHULUAN}

Salah satu fungsi saliva dalam menjaga kesehatan rongga mulut terkait dengan derajat keasaman $(\mathrm{pH})$ rongga mulut. Karies merupakan degenerasi fokal dari gigi akibat dari larutnya mineral-mineral penyusun struktur gigi oleh paparan asam organik hasil fermentasi karbohidrat yang dilakukan oleh bakteri patogen di dalam rongga mulut, salah satunya adalah Streptococcus mutans. Asam laktat hasil fermentasi tersebut akan menurunkan keasaman $(\mathrm{pH})$ mulut, dimana penurunan $\mathrm{pH}$ mulut dibawah 5,5 akan menyebabkan terjadinya demineralisasi email (Roeslan, 2002).

Saliva adalah cairan mulut yang dikeluarkan oleh kelenjar ludah. Saliva berperan dalam mencegah penyakit gigi dan mulut salah satu hal yang harus di perhatikan adalah derajat keasaman $(\mathrm{pH})$ saliva. pada $\mathrm{pH}$ normal saliva berfungsi mengurangi pertumbuhan bakteri, membantu pertumbuhan sel kulit epitel, mengurangi akumulasi plak dan mengaktifkan kerja enzim. Salah satu tindakan mempertahankan $\mathrm{pH}$ saliva yaitu dengan menggunakan madu. (Septiano, 2013).

Madu alami banyak mengandung enzim, yaitu molekul protein yang sangat komplek, yang dihasilkan oleh sel hidup dan berfungsi sebagai katalisator, yakni: zat pengubah kecepatan reaksi dalam proses kimia yang terjadi di dalam tubuh setiap makhluk hidup. Madu mengandung antibiotik sebagai antibakteri dan antiseptik menjaga luka (Purbajaya, 2007). Karies merupakan suatu penyakit jaringan keras gigi, yaitu email, dentin, dan sementum, yang disebabkan oleh aktivitas suatu jasad renik dalam suatu karbohidrat yang dapat diragikan. Tandanya adalah adanya demineralisasi atau hilangnya mineral dari struktur gigi yang kemudian diikuti oleh kerusakan bahan organiknya. Proses pembentukan karies diawali dari beberapa jenis karbohidrat makanan misalnya sukrosa dan glukosa yang kemudian diragikan oleh bakteri tertentu dan membentuk asam sehingga $\mathrm{pH}$ plak akan menurun sampai di bawah 5 dalam tempo 1-3 menit. Penurunan $\mathrm{pH}$ yang berulang-ulang dalam waktu tertentu akan mengakibatkan demineralisasi permukaan gigi yang rentan dan proses kariespun dimulai (Kidd dan Bechal, 2013).

Sekolah Dasar Muhamadiyah Sambisari Purwomartani Kalasan mempunyai siswa sebanyak 205. Berdasarkan studi pendahuluan dengan kepada 16 siswa SD Muhammadiyah Sambisari dengan pemeriksaan saliva siswa rata-rata $\mathrm{pH}$ saliva kurang dari 7 dibawah normal. Berdasarkan pemeriksaan status kesehatan gigi mempunyai karies gigi ratarata 2, maka peneliti tertarik untuk melakukan penelitian tentang pengaruh mengkonsumsi minuman madu terhadap $\mathrm{pH}$ saliva pada siswa didik SD Muhammadiyah Sambisari.

Tujuan penelitian adalah mengetahui rata-rata tingkat keasaman $\mathrm{pH}$ saliva sebelum dan sesuah mengkonsumsi minuman madu.

\section{METODE PENELITIAN}

Jenis penelitian yang digunakan adalah penelitian eksperimen semu/quasi experiment. Rancangan penelitian menggunakan Rancangan Pretest Posttest control group.

$\begin{array}{lccc} & \text { Pretes } & \text { Perlakuan } & \text { Postes } \\ \text { Kelompok eksperimen } & 0_{1} & \mathrm{X}_{1} & 0_{2} \\ \text { Kelompok kontrol } & 0_{3} & \mathrm{X}_{2} & 0_{4}\end{array}$

Keterangan:

$0_{1}$ : pemeriksaan $\mathrm{pH}$ saliva awal kelompok eksperimen

$\mathrm{X}_{1}$ : perlakuan mengkonsumsi minuman madu pada kelompok eksperimen

$\mathrm{X}_{2}$ : kelompok kontrol tidak minum madu, diberikan air mineral

$\mathrm{O}_{2}$ : pemeriksaan $\mathrm{pH}$ saliva akhir kelompok eksperimen

$0_{3}$ : pemeriksaan $\mathrm{pH}$ saliva pada kelompok kontrol

$0_{4}$ : pemeriksaan $\mathrm{pH}$ saliva pada kelompok kontrol 
Pengambilan sampel secara random sampling sebanyak 60 siswa pada kelas III, IV dan V dengan kriteria umur 9 - 12 tahun dan bersedia menjadi responden. Tahapan penelitian dimulai dengan responden melakukan menyikat gigi dengan pasta gigi rasa original (homogen) setelah itu pengukuran $\mathrm{pH}$ saliva kepada kedua kelompok responden, kelompok satu diberikan minuman madu sebanyak satu sendok makan madu dan pada kelompok kontrol tidak diberikan perlakukan (air mineral). Selanjutnya akan dilakukan pengukuran $\mathrm{pH}$ saliva kembali kepada kedua kelompok. Data diperoleh dan di analisis dengan Uji T-Test Paired Samples T Test dan Independent Samples T Test

\section{HASIL DAN PEMBAHASAN}

Data hasil penelitian diolah dengan menggunakan analisis Paired Samples T Test dan Independent Samples T Test dan tersaji dalam tabel berikut :

Tabel 1. Distribusi Frekuensi Responden Berdasarkan Rata-rata Nilai pH Saliva

\begin{tabular}{lccc}
\hline \multicolumn{1}{c}{ Variabel } & \multicolumn{2}{c}{ Mean } & \multirow{2}{*}{ Selisih } \\
& Sebelum & Sesudah & \\
\hline $\begin{array}{l}\text { Mengkonsumsi } \\
\text { Minuman Madu }\end{array}$ & 6,93 & 6,64 & $-0,24$ \\
$\begin{array}{l}\text { Tidak } \\
\text { Mengkonsumsi }\end{array}$ & 7,07 & 7,24 & 0,17 \\
Minuman Madu & & & \\
\hline
\end{tabular}

Tabel 1 menunjukkan nilai $\mathrm{pH}$ saliva pada kelompok eksperimen sesudah mengkonsumsi minuman madu mengalami penurunan dari sebelum mengkonsumsi minuman madu, yaitu dari 6,93 menjadi 6,64 sedangkan pada kelompok kontrol sesudah dilakukan pengukuran nilai $\mathrm{pH}$ saliva yang kedua mengalami peningkatan dari pengukuran nilai $\mathrm{pH}$ saliva yang pertama yaitu dari sebelumnya 7,07 menjadi 7,24.
Tabel 2. Hasil Analisis Menggunakan Uji Paired Samples T Test Nilai pH Saliva Sebelum dan Sesudah Mengkonsumsi Minuman Madu

\begin{tabular}{cccc}
\hline $\mathrm{N}$ & $\mathrm{T}$ & Asymp. Sig & A \\
\hline 30 & 2,046 & 0,050 & 0,05 \\
\hline
\end{tabular}

Tabel 2 menunjukkan bahwa nilai Asymp. Sig adalah 0,05 sama dengan nilai A 0,05 jadi Ho ditolak dan Ha diterima, maka secara statistik menunjukkan adanya perbedaan yang bermakna antara nilai $\mathrm{pH}$ saliva siswa siswi kelas III, IV, dan V SD Muhammadiyah Sambisari sebelum dan sesudah mengkonsumsi minuman madu.

Tabel 3. Hasil Analisis Menggunakan Uji Independent Samples T Test Perbedaan Selisih

Nilai pH Saliva antara Siswa Siswi yang Mengkonsumsi Minuman Madu dengan Siswa Siswi yang tidak Mengkonsumsi Minuman Madu

\begin{tabular}{cccc}
\hline $\mathrm{N}$ & $\mathrm{t}$ & Asymp. Sig & $\mathrm{A}$ \\
\hline 30 & 2,094 & 0,041 & 0,05 \\
\hline
\end{tabular}

Tabel 3 menunjukkan bahwa nilai Asymp. Sig perbedaan selisih nilai $\mathrm{pH}$ saliva antara siswa siswi yang mengkonsumsi minuman madu dengan siswa siswi yang tidak mengkonsumsi minuman madu adalah 0,041 lebih kecil dari 0,05 jadi Ho ditolak dan $\mathrm{Ha}$ diterima, maka dapat disimpulkan bahwa adanya perbedaan yang bermakna pada nilai $\mathrm{pH}$ saliva antara siswa siswi yang mengkonsumsi minuman madu dengan siswa siswi yang tidak mengkonsumsi minuman madu.

Hasil penelitian (lihat Tabel 1) menunjukkan bahwa nilai rata-rata $\mathrm{pH}$ saliva siswa-siswi kelas III, IV, dan V SD Muhammadiyah Sambisari setelah mengkonsumsi minuman madu mengalami penurunan atau menjadi lebih asam yaitu dari 6,93 menjadi 6,64, sedangkan pada siswasiswi yang tidak mengkonsumsi minuman madu mengalami peningkatan nilai rata-rata $\mathrm{pH}$ saliva atau menjadi lebih basa yaitu dari 7,07 menjadi 7,24. Berdasarkan tabel 2 didapatkan bahwa nilai $\mathrm{pH}$ saliva sebelum mengkonsumsi minuman madu dan sesudah mengkonsumsi minuman madu 
signifikansinya adalah $\mathrm{p}=0,05$ nilai $\mathrm{p}=0,05$, maka terdapat perbedaan yang bermakna mengkonsumsi minuman madu terhadap nilai $\mathrm{pH}$ saliva siswa-siswi kelas III, IV, dan V SD Muhammadiyah Sambisari.

Perbedaan ini disebabkan karena menurunnya nilai $\mathrm{pH}$ saliva siswa setelah mengkonsumsi minuman madu tetapi masih dalam standar normal nilai $\mathrm{pH}$ saliva yaitu dari 6,93 menjadi 6,64. Sesuai dengan hasil penelitian yang dilakukan oleh Sari, (2008) yang menyatakan bahwa nilai $\mathrm{pH}$ rata-rata setelah mengkonsumsi air madu menunjukkan adanya penurunan, yaitu dari 7,40 menjadi 6,94. Meskipun demikian, penurunan nilai $\mathrm{pH}$ ini ternyata tidak mencapai nilai $\mathrm{pH}$ kritis $(\mathrm{pH}<5,5)$. Penurunan nilai $\mathrm{pH}$ ini terjadi dikarenakan setelah saliva terstimulasi oleh air madu, terjadi pemecahan karbohidrat menjadi asam laktat. Akibatnya, terjadi penurunan $\mathrm{pH}$ di dalam lingkungan rongga mulut. Faktor lainnya yang mungkin menyebabkan turunnya nilai $\mathrm{pH}$ setelah mengkonsumsi air madu adalah karena madu memiliki nilai $\mathrm{pH}$ yang asam.

Penelitian ini didukung oleh Illahi (2014) yang menyatakan bahwa derajat keasaman $\mathrm{pH}$ saliva berkisar antara 6,8-7,2 tergantung pada perbandingan antara asam dan basa konjugat yang bersangkutan. Derajat asam dan kapasitas bufer terutama dipengaruhi oleh susunan bikarbonat. Derajat keasaman $(\mathrm{pH})$ saliva optimum untuk pertumbuhan bakteri 6,5-7,5 dan apabila rongga mulut $\mathrm{pH}$-nya rendah antara 4,5-5,5 akan memudahkan pertumbuhan kuman asidogenik seperti Streptococcus mutans dan Lactobacillus.

Hasil analisis menggunakan uji Paired Samples T Test menunjukkan bahwa nilai $\mathrm{pH}$ sebelum dan sesudah mengkonsumsi minuman madu terdapat perubahan, terbukti dengan hasil signifikansi sebesar $0,05=0,05$ yang berarti bahwa Ho ditolak dan Ha diterima, dengan demikian menunjukkan bahwa mengkonsumsi minuman madu mempengaruhi secara signifikan menurunnya nilai $\mathrm{pH}$ siswa siswi kelas III, IV, dan V Sekolah Dasar Muhammadiyah Sambisari Purwomartani Kalasan Sleman Yogyakarta. Penelitian ini didukung oleh Hudri (2014) mengungkapkan bahwa secara umum madu memiliki $\mathrm{pH}$ ratarata 3,9 dengan rentang antara 3,4-6,1 dan kandungan asam $0,57 \%$ dengan rentang $0,17-1,17 \%$ terutama asam glukonat. Nilai $\mathrm{pH}$ madu yang cukup rendah ini disebabkan oleh beberapa kandungan asam organik yang terdapat dalam madu.

Sesuai juga dengan pendapat Putri (2014) yang menyatakan bahwa nilai $\mathrm{pH}$ madu rata-rata 3,2-4,5, sehingga dapat menghambat pertumbuhan beberapa patogen yang mempunyai $\mathrm{pH}$ minimum pertumbuhan sekitar 7,2-7,4, seperti Escheria coli, Salmonella, Pseudomonas aeruginosa dan Streptococcus pyogenes.

Mottalebnejad dalam penelitian Sutari dkk (2013) juga menyatakan bahwa efek madu untuk menurunkan disfungsi rongga mulut dikaitkan dengan sifat higroskopis madu, keasaman $\mathrm{pH}$ madu, kemampuan madu untuk mengobservasi hidrogen peroksida dari glukosa oksidase dan gluconic acid serta kandungan enzim, vitamin dan mineral di dalam madu yang berguna untuk perbaikan jaringan secara langsung.

Penelitian ini juga didukung oleh pendapat Haviva dalam penelitian Fione dkk (2013) yang menyatakan bahwa madu sangat efektif untuk mencegah kerusakan gigi, di dalam madu terdapat kandungan senyawa yaitu asam organik, asam amino, mineral, enzim, gula, vitamin, dan kalori. Asam organik di dalam madu menjadi bukti tentang ketahanan madu terhadap ada atau tidaknya pertumbuhan mikroba, khususnya bakteri penyebab penyakit (patogen) dan bakteri yang menghasilkan racun. Adapun kandungan asam organik yang dimaksud adalah sebagai berikut : asam asetat, asam format, asam glukonat, asam oksalat, asam piroglutamat, asam suksinat, asam laktat, asam malat, asam glikolat, asam butirat, asam sitrat, asam piruvat, dan asam tartrat. 
Hasil analisis dengan menggunakan uji Independent Samples T Test (lihat Tabel 3) didapatkan adanya perbedaan yang bermakna antara selisih nilai $\mathrm{pH}$ saliva siswa-siswi yang mengkonsumsi minuman madu dengan yang tidak mengkonsumsi minuman madu, dibuktikan dengan nilai signifikansi $0,041<0,05$. Sesuai dengan pendapat Purbaya dalam penelitian Fione dkk (2013) yang menyatakan bahwa kandungan mineral yang terdapat pada madu bisa meningkatkan produksi saliva atau cairan ludah yang dapat menjaga keseimbangan $\mathrm{pH}$ saliva di dalam rongga mulut.

Penelitian ini juga didukung oleh Amerongen dalam penelitian Fione dkk (2013) yang menyatakan bahwa kecepatan sekresi ludah (saliva) mempengaruhi derajat keasaman $(\mathrm{pH})$ dalam mulut, kecepatan sekresi dipengaruhi oleh jenis dan sifat rangsangan rasa manis dan asam, yang mana madu alami mempunyai rasa yang manis. Setelah madu masuk ke dalam rongga mulut akan bercampur dengan saliva dalam rongga mulut dan sifat madu yang dapat membunuh mikroorganisme patogen dapat menurunkan jumlah bakteri dalam rongga mulut. Sari (2008) dalam penelitiannya juga menyatakan bahwa madu memiliki kandungan antimikroba yang efektif baik terhadap bakteri gram negatif maupun gram positif. Zat antimikroba dalam madu, yaitu hidrogen peroksida dapat menghambat pertumbuhan bakteri Streptococcus mutans, dan mengurangi jumlah produk asam yang dihasilkan plak. Sesuai juga dengan hasil penelitian yang dilakukan oleh Fadly (2010) yang menyatakan bahwa pemberian kumurkumur madu $20 \%$ jumlah total temuan mikroorganisme pada hasil swab mukosa buccalis hingga $75 \%$.

\section{KESIMPULAN}

1. Adanya pengaruh yang signifikan minuman madu terhadap nilai $\mathrm{pH}$ saliva siswa-siswi kelas III, IV, dan V SD Muhammadiyah Sambisari.

2. Ada perbedaan nilai $\mathrm{pH}$ pada siswa-siswi yang mengkonsumsi minuman madu dengan siswa-siswi yang tidak mengkonsumsi minuman madu.

3. Nilai rata-rata $\mathrm{pH}$ sebelum dan sesudah siswa-siswi mengkonsumsi minuman madu memiliki penurunan nilai berarti $\mathrm{pH}$ menjadi lebih asam setelah mengkonsumsi minuman madu. Sedangkan pada siswa-siswi yang mengkonsumsi minuman madu memiliki perubahan $\mathrm{pH}$.

\section{DAFTAR PUSTAKA}

Fadly, A. 2010. Pengaruh Pemberian Madu terhadap Mikroorganisme pada Rongga Mulut Mahasiswa PSPD UIN Tahun Angkatan 200. Skripsi. Program Studi Kedokteran Fakultas Kedokteran dan Ilmu Kesehatan UIN Syarif Hidayatullah. Jakarta.

Fione, Roose, V., Maramis, J.L, dan Meylandari, D. P., 2013, Pengaruh Berkumur dengan Larutan Madu terhadap pH Saliva pada Wanita Kaum Ibu Jemaat Getsemani Desa Senduk Kecamatan Tombariri. Jurnal Jurusan Keperawatan Gigi Poltekkes Kemenkes Manado JIK. 7 (2).

Hudri, F.A. 2014, Uji Efektivitas Ekstrak Madu Multiflora dalam Menghambat Pertumbuhan Bakteri Salmonella typhi. Skripsi Program Studi Pendidikan Dokter Fakultas Kedokteran dan Ilmu Kesehatan Universitas Islam Negeri Syarif Hidayatullah. Jakarta.

Illahi, G. N 2014, Pengaruh Mengkonsumsi Saus Tomat terhadap Kadar $\mathrm{pH}$ Mulut. Skripsi Bagian Ilmu Kedokteran Gigi Masyarakat 
Fakultas Kedokteran Gigi Universitas Hasanuddin. Makassar.

Putri, N.N. 2014, Manfaat Mengkonsumsi Campuran Larutan Madu dan Bubuk Kayu Manis terhadap Penurunan Tingkat Halitosis. Skripsi Fakultas Kedokteran Gigi Universitas Mahasaraswati Denpasar. Bali.

Purbajaya, J.R, 2007, Mengenal dan Memanfaatkan khasiat madu alami, Pionir Jaya, Bandung

Kidd dan Bechal, 2013, Dasar-Dasar Karies Gigi Penyakit dan Penanggulangannya. ECG, Jakarta

Roeslan, B.O., 2002, Imunologi Oral Kelainan di dalam Rongga Mulut, FKUI, Jakarta.

Septiano, 2013, Pengaruh Konsumsi Madu Terhadap Derajad Keasaman ( $\mathrm{HH})$ Saliva Anak Sekolah Di SD Negeri I Wulung

Sari, C.P. 2008, Perbandingan Nilai Viskositas, $\mathrm{pH}$, dan Kapasitas Dapar Saliva Setelah Mongonsumsi Air Madu dan Air Gula Sukrosa. Skripsi Program Studi Kedokteran Gigi Universitas Indonesia. Jakarta.

Sutari, Anik, I.G.A., Gunahariarti, N., dan Suindrayasa, I. M., 2014, Pengaruh Systematic Oral Care dengan Madu terhadap Disfungsi Rongga Mulut akibat Kemoterapi pada Anak Usia 312 Tahun. Jurnal Penelitian Program Studi Ilmu Keperawatan Fakultas Kedokteran Universitas Udayana. Bali. 